\title{
Toelating tot die nagmaal: 'n Gereformeerd-kerkordelike perspektief
}

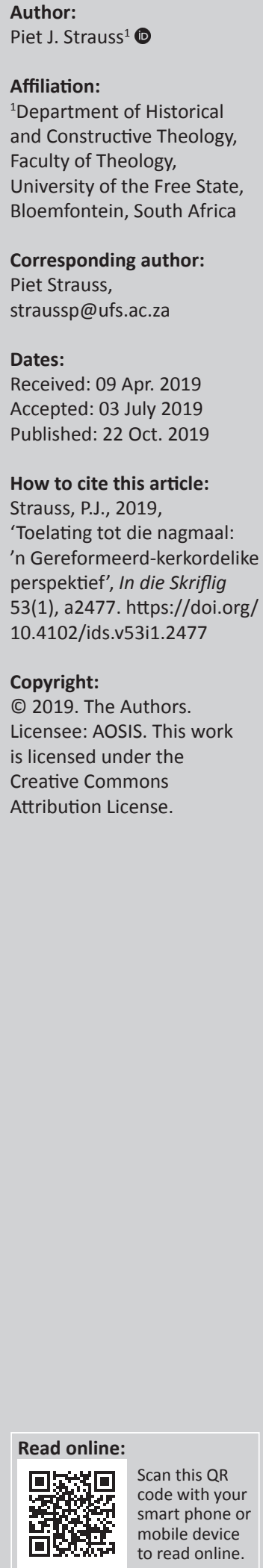

\begin{abstract}
Allowed to partake in holy communion: A perspective through Reformed church orders. Reformed Churches with church orders linked to the Dordt Church Order (DCO) of 1619 in some or other way, often use an own replica of, or DCO article 61 itself in this church order. That means that they keep to a closed or limited allowance to holy communion. Only those who can give an account of their faith in Christ, are allowed to partake in the sacrament. In these circles it is accepted that the sacrament of baptism quarantees the introduction of those who are baptised in the covenant of God's grace and of his church, and that the sacrament of the holy communion confirms and quarantees their staying in this covenant. That means that faith in Christ, in order to receive the full effect or blessing of holy communion as a sacrament, is a core condition to partake in it.
\end{abstract}

Keywords: Controlled communion; confession of faith as condition; communion overseen by church; four elements of sacrament; mark of true church; church in unity.

\section{Inleidend}

In sy kommentaar op die Dordtse Kerkorde (DKO) 1619 artikel 61 wat toelating tot die gebruik van die nagmaal in gemeentes of kerke ${ }^{1}$ reël, maak De Gier (1989) opmerkings wat daarop dui dat hy die elemente van hierdie saak vanuit 'n Gereformeerd-kerkordelike perspektief goed raakvat.

Volgens De Gier het Christus die nagmaal ingestel die nag toe Hy verraai is. Hy het dit ingestel sodat diegene wat Hom as Verlosser deur 'n ware geloof leer ken het en uit sy genade lewe, dit tot versterking van hulle geloof kan gebruik. Die nagmaal mik nie op wedergeboorte en geloof by die gebruiker nie, maar veronderstel dit. Die nagmaal is 'n sakrament om God se genade en die Christelike geloof in die gebruiker te bevestig, te waarborg en te verseël (kyk De Gier 1989:291; Heidelbergse Kategismus Sondag 25 in NG Kerk-Uitgewers 1982:56; Calvyn IV s.a.:314-315). Die nagmaal bevestig dat die gebruiker as 'n gelowige kan groei in die genade en in sy kennis van Christus. $^{2}$

De Gier (1989:291) wys daarop dat DKO 1619 in artikel 61-64 aan die nagmaal aandag gee uit 'n 'kerkrechtelijke zijde'. Getrou aan 'n Gereformeerde kerkorde dek DKO 1619 die nagmaal nie in elke opsig nie, maar word tot die 'meest noodzakelijke bepalingen' beperk wat vir die goeie orde met die bediening van die nagmaal in die kerk nodig is. Volgens hom is ' $n$ kerkorde nie ' $n$ wetboek wat vir elke moontlike geval voorsiening maak nie, maar 'n 'kerklijke ordening' wat hoofbeginsels in 'n beperkte aantal artikels verwoord en die gestaltegewing of toepassing daarvan aan die mondige oordeel van 'n gemeente of kerkverband oorlaat. Die kerkorde wil deur sy artikels verseker dat bybelse norms nie deur menslike bepalings in die kerkregering verdring word nie (De Gier 1989:291; Strauss 2010:4). In sy kommentaar op DKO 1619, laat De Gier hom ook deur verantwoorde vereistes vir 'n Gereformeerde kerkorde lei (Jonker 1960:36).

Hierdie standpunt van De Gier beteken dat toelating tot die nagmaal uit 'n kerkordelike oogpunt tot Christengelowiges beperk word. Daarmee bevestig hierdie standpunt een van vier aspekte waaruit die nagmaal as 'n sakrament bestaan: eerstens, die Christelike geloof waardeur die nagmaal gebruik word. Die ander drie aspekte is die tekens van brood en wyn wat aan die betekende saak (die sterwe van Christus aan die kruis) deur die Skriflesing, preek en formulier verbind word sowel as deur die Heilige Gees en die geloof wat deur mense ontvang word. Die gebruiker eet die

1.In sekere Gereformeerde kerke word daar na gemeentes as "kerke' verwys. Hierdie gebruik hang saam met artikel 29 van die Nederlandse Geloofsbelydenis (NGB) uit 1561 waarin daar op die drie merktekens of kenmerke van die ware kerk gewys word. Merktekens wat in die gemeente aangetref word en daarvan volledig kerk maak, is die suiwere Woordgeoriënteerde bediening van die Merktekens wat in die gemeente aangetref word en daarvan volledig kerk maak, is die suiwere Woordgeo
Woord sowel as die sakramente en die handhawing van die kerklike tug (NG Kerk-Uitgewers 1982:29).

2.In sy onderskeid tussen doop en nagmaal, noem Heyns die doop by geleentheid die inlywing, en die nagmaal die inblywing in God se genadeverbond (vgl. Calvyn IV sa:347, 369; Du Plooy 1990:148-149, 152; Smit \& Van der Walt 1989:65). 
brood en drink die wyn by die maaltyd in die geloof. So vorm die nagmaal 'n genademiddel uit God se hand wat sy of haar geloof versterk. Hierdie standpunt impliseer by voorbaat die uitsluiting van nie-gelowiges uit die effektiewe werking van die sakrament, want sonder die gebruik daarvan deur die geloof, ontvang die gebruiker geen verseëlende sakrament of geestelike waarborg dat Christus vir hom of haar aan die kruis gesterf het nie - al sou hy of sy die uiterlike tekens daarvan inneem (Strauss 2010:98).

Elke sakrament het as 'n bybelse sakrament vier aspekte: Eerstens werk die sakrament deur God die Heilige Gees. Die Heilige Gees is die Brugbouer wat met die teken en betekende saak (soos deur die Woord geskets), die hart van die gelowige gebruiker in besit neem. Die Heilige Gees bou die brug na die gelowige hart van die gebruiker met die saak waarvoor die sakrament staan. Die Gees bewerk deur die Woord geloof in God-Drieënig en bevestig of verseël hierdie geloof deur die verduidelikende Woord plus die tekens van brood en wyn. Tweedens gaan dit om die tekens wat in 'n eenvoudige oervorm ${ }^{3}$ deel van die sakrament vorm: gewone water $\left(\mathrm{H}_{2} \mathrm{O}\right)$ by die doop en (as gevolg van die gebruik, meestal rooi) soetwyn en (wit) bakkersbrood by die nagmaal. Derdens behels dit die toegespitsde Woord in formulier- en preekvorm wat die tekens in ' $n$ nuwe konteks plaas en daaraan ' $n$ heilsbetekenis gee soos ' $n$ ring aan die vinger, wat in die konteks van die verlowing of huweliksluiting, 'n romantiese betekenis kry. Die liefde en trou van die egpaar vir mekaar word deur 'n ring bevestig, verseël en sigbaar uitgedruk. Die Heilige Gees as die Brugbouer tussen die teken, die betekende saak en die geloof van die gebruiker, werk daarmee as die Verseëler van die saak in die hart van die gebruiker (vgl. die boektitel van Heyns 1973; vgl. ook 1992:369-372; Strauss 2010:98).

Die waarborgeffek van God se beloftes deur die nagmaal werk deur hierdie vier aspekte. Toelating tot die nagmaal deur kerklike instansies sowel as toetrede tot die nagmaal deur sogenaamde vrye individue wat self kies, moet albei hiermee rekening hou.

Geloof by die gebruiker as ' $n$ vereiste vir toelating tot die nagmaal, word in die praktyk deur medegelowiges in die kerkraad, of alternatiewelik, deur die gebruiker self bepaal. Gereformeerdes in Nederland in die 1600's het op hierdie punt met Duifhuis, Erastus en die Remonstrante gebots wat die toets vir sy of haar geloof aan die gewete van die gebruiker self wou oorlaat. Vanuit 'n humanisties-individualistiese hoek moes elkeen, volgens hulle standpunt, vir hom- of haarself besluit wat gangbaar is. Die kerk met sy Godgegewe kerklike toesig as 'n meer onpartydige en ewewigtige eksterne oordeel, kon volgens die Remonstrante nié hieroor besluit nie. In sogenaamde vrye Gereformeerde kerke word selferkende gelowiges net so tot die nagmaal toegelaat en moet elkeen self besluit of hy of sy hom of haar daarby voeg

3.Van wyk (1991:246, 261) beklemtoon dat die nagmaal in die Bybel die vorm van ' $n$ maaltyd aangeneem het waar gewone ongesuurde brood en normale gegiste wyn gebruik is. Die keuse van watter soort brood en wyn ag Van Wyk (1991:247), op spoor van Calvyn, egter as 'n middelmatige saak waaroor daar verskil kan word. of nie. Die Nederlandse Gereformeerde Kerk van destyds soos sekere gereformeerdes vandag - kon hierdie individuele vryheid egter nie aanvaar nie. Vir hulle was die nagmaal nie ongekwalifiseerd oop nie. Soos in ander kwessies van leer en lewe moes die kerk gesamentlik of deur sy besluitorgane hiervoor die groen lig gee (De Gier 1989:291; Jansen 1952:267). Ook hier is van Paulus se opmerking in Efesiërs 3:18 gebruik gemaak: 'Mag julle in staat wees om saam met al die gelowiges te begryp hoe wyd en ver en hoog en diep die liefde van Christus strek ...'.

Nagmaalsgebruik met die geloof as 'n voorwaarde vir toelating, plaas die vereistes vir die gebruik van die nagmaal in Gereformeerde kerke op die agenda. As die Christelike geloof 'n vereiste vir die sinvolle gebruik van die nagmaal is, hoe word hierdie geloof by mense bepaal? Juis omdat die saak hier vanuit die hoek van Gereformeerde kerkordes en Gereformeerde kerkregering ondersoek word, ontstaan die volgende vraag: Watter rol speel kerklike instellings - die toepassers van 'n kerkorde - in die saak; of gooi die kerk soos 'n verbruikerswinkel sy nagmaalsdeure oop vir almal wat belangstel? Watter sin het sekere bepalings of vereistes waaraan daar voldoen moet word om tot die nagmaal in 'n Gereformeerde kerk toegelaat te word?

\section{Dordtse Gereformeerdes teen 'oop' nagmaal}

Die Gereformeerd-kerkordelike perspektief wat hier aan die orde kom, spruit uit kerkordes wat een of ander band met DKO 1619 het en so 'n Nederlands-Gereformeerde kleur vertoon. ' $n$ Ander benaming hiervoor is die DordtsGereformeerde tradisie waarin die saak van belydenis en kerkorde 'n rigtinggewende rol speel. Die Dordtse Sinode van 1618-1619 het immers die Drie Formuliere van Eenheid as belydenisskrifte wat die geloofseenheid van hierdie gereformeerdes verwoord, ${ }^{4}$ aanvaar en DKO 1619 in dieselfde jaar goedgekeur - twee uitstaande, rigtinggewende punte op hierdie Sinode.

Dordrecht 1618-1619 word deur die bekende ekklesioloog, H.H. Kuyper, as 'n Sinode bestempel wat die erenaam van 'het Gereformeerde oecumenische concilie' dra. Hoewel die Nederlanders op die Sinode alleen op DKO 1619 as hulle kerkorde besluit het, het die afgevaardigdes van Gereformeerde kerke in Nederland (GKN), Engeland, Switserland en Duitsland saam op die Drie Formuliere van Eenheid besluit as belydenisskrifte wat hulle geloofseenheid uitdruk. Tipies van die aard van 'n gereformeerde belydenisskrif, moes meer as net plaaslike gelowiges die kernwaarhede wat hierdie geskrifte verwoord as Skriftuurlik herken en bely. Belydenisskrifte moet so duidelik bybels wees en hartswaarhede verwoord sodat dit is nie polemies of kwasterig is nie, maar vanuit die hart bely word. Hierdie vereiste beteken egter nie dat ' $n$ belydenis net aanvaarbaar

4.Dit gaan hier om die Nederlandse Geloofsbelydenis van 1561, die Heidelbergse Kategismus van 1563 en die Dordtse Leereëls van 1619 (NG Kerk-Uitgewers 1982:9, Kategismus van 1563 en die Dordtse Leereëls van 1619 (NG Kerk-Uitgewers 1982:9,
39,77 ) en die leer soos vervat in, of 'begrepen in' hierdie geskrifte (Strauss 39, 77) en die
2006:662-663) 
is indien alle gelowiges dit aanvaar nie (Strauss 2010:7; 2012:75).

In sy kommentaar op DKO 1619 artikel 61 verklaar De Gier (1989) sonder meer:

De gereformeerden verklaarden zich tegen een 'open Avondmaal' voor iedereen die maar wilde. Zij spraken op grond van 1 Corinthe 11:28 uit, dat men voor het deelnemen aan het Avondmaal gekomen moest zijn op een leeftijd, waarop men bekwaam was om het gewicht en de belangrijkheid, de aard en het wezen van het Avondmaal te kunnen beoordelen ... Bovendien heeft de kerk de taak het Avondmaal heilig te houden, waarom een onderzoek naar leer en leven vooraf behoort te gaan ... (p. 291)

Du Plooy (1990) loop dus op die spoor van die DordtsGereformeerde tradisie wanneer hy aanvoer dat die nagmaal nie 'n oop nie, maar 'n geslote maaltyd is. Volgens hom is die nagmaal oop vir hulle wat hulleself 'onderwerp' aan die verkondiging van die evangelie as die sleutelmag wat die koninkryk van die hemel oopsluit vir hulle wat dit glo en aanvaar, maar toesluit vir hulle wat dit verwerp (Heidelbergse Kategismus Sondag 31, NG Kerk-Uitgewers 1982:62). 'n Hemel wat vir die gelowiges oopgaan omdat die Heilige Gees deur die evangelie hulle harte oopsluit, open ook die nagmaal vir hulle as ' $n$ dis tot die verseëling van hulle geloof (Du Plooy 1990:155; Heidelbergse Kategismus Sondag 31 vraag en antwoord 83-85, NG KerkUitgewers 1982:62-63).

Calvyn verwys na die doop as die inseëning van 'n mens in die genadeverbond van God. Die doop verseël God se belofte van die wederbaring van mense om sy geestelike kinders te wees. Die nagmaal gaan oor die voed van die geloof van God se kinders om lewensomvattend gehoorsaam aan God te lewe. Hierdie voeding veronderstel dat hulle wat by sy tafel aansit, sy gelowige kinders is wat uit elke woord of boodskap wat daar van Hom uitgaan, leef en sy woorde gelowig eet (Calvyn IV s.a.:347, 411). Vir Du Plooy (1990:149) is die doop die 'beseëling' van die inlywing in die genadeverbond en die wedergeboorte waardeur die kerk ontstaan of in aansyn geroep word. Hierdie afgrensing van die kerk as die nuwe mensdom in die ou wêreld omvat alle gelowiges en hulle geslagte. Wat hom betref, wil die Here deur die nagmaal hierdie afgrensing van die kerk 'bewaar en versterk'. Die nagmaal bou en versterk die kerk in sy geloofseenheid met God en met mekaar (Du Plooy 1990:149).

Jansen bevestig die argument van 'n 'geslote kommunie' as hy aanvoer dat toelating tot die nagmaal by Nederlandse Gereformeerdes 'van den beginne aan ... niet vrij' was. Die nagmaal was nie oop vir elke gedoopte nie. Die kerke of gemeentes wou of kon alleen belydende gelowiges tot die 'verbondsdis' (De Gier 1989:291 se term) toelaat. Hulle kon niemand toelaat wat nie daarby 'hoort' nie. Hy wys op die bekende Utrechtse kerkregtelike, Gisbertus Voetius (1589-1676; De Jong 1987:266), wat daarteen gekant was dat elke gedoopte tot die nagmaal toegelaat word. 'Het is niet genoeg, dat het vermogen des geloofs in de wedergeboorte aanwezig is, ook de bekering moet er wezen' (Jansen 1952:268).

Teen hierdie agtergrond bepaal DKO 1619 artikel 61 dat niemand tot die nagmaal toegelaat word nie, behalwe diegene wat volgens die gebruik van die kerk 'n belydenis van die gereformeerde godsdiens afgelê het en oor die getuienis van 'n vroom lewenswandel beskik. Hierdie vereiste geld ook vir hulle wat uit ander Gereformeerde kerke of uit kerke buite die kerkverband kom (Pont 1981:183).

\section{Gereformeerde belydenis toelating tot nagmaal: Gereformeerde kerke in Nederland}

In 'n poging om die nagmaal en die kerklike lewe heilig of Skriftuurlik te hou, het die gereformeerdes op die DordtsGereformeerde lyn besluit dat die toelating van mense tot die nagmaal deur'n ondersoek na hulle leer en lewe voorafgegaan moes word. Hierdie ondersoek word deur die voorgeskrewe selfondersoek van 1 Korintiërs 11:28 gestimuleer. Vir 'n soortgelyke ondersoek moes dooplidmate en oningewydes in die gemeente vooraf in die kerklike of Christelike leer geskool word (De Gier 1989:291). Jansen voeg hierby dat dit 'n kerklike ondersoek na leer en lewe (hart, verstand en daad) moes wees - 'n ondersoek na die stand van, soos dit verwoord is, die 'gereformeerde religie' by die betrokke persoon. Dit het beteken dat iemand genoeg kennis van die Skrif en die gereformeerde belydenis moet besit vir 'n sinvolle gebruik van die nagmaal en 'n aktiewe lidmaatskap van die kerk moes openbaar. Daar moes ' $n$ bevredigende getuienis van so 'n persoon se Christelike lewenswandel wees waarvan sy of haar kerklike lewe deel is. Hoewel die ondersoek na leer en lewe voor die kerkraad of ' $n$ kommissie van die kerkraad kon plaasvind, is die belydenis vir 'n publieke diens of 'n gemeentelike geleentheid geoormerk. Hierna sou die deelname aan 'n sakrament kon volg wat - dit was die bepaling - ook in 'n erediens van die gemeente plaasvind. As gevolg van die feit dat die Nederlandse Gereformeerde Kerk in sy verband nie vrae vir gebruik hiervoor in gemeentes vasgestel het nie, moes hulle self daarvoor sorg. Sommige kerke of gemeentes het van Voetius se vrae gebruik gemaak, terwyl ander óf hulle eie óf die vrae van die klasssis gebruik het. Eers by die Sinode van Utrecht in 1923 het die GKN 'n formulier met vier vrae aanvaar, wat hierdie belydenis met die oog op toelating tot volle lidmaatskap en dus tot die sakramente fasiliteer (Jansen 1952:268-269; Nauta 1971:270).

Hiermee het die gereformeerdes in Nederland vir Calvyn gevolg wat die Lutherse konfirmasie afgeskaf en met die aflegging van 'n openbare belydenis van geloof vervang het. Hierdie belydenis het aan persone toegang tot die nagmaal gegee. Die belydenis volg op kerklike onderrig uit die (vir die Waalse of Franssprekendes) Kategismus van Calvyn, of (vir die Nederlandssprekendes) uit die Heidelbergse Kategismus. In Calvyn se tyd is hierdie onderrig gesamentlik deur die ouers, die skool en die predikant aangepak. Dit het oor 
die waarhede van die Christelike geloof gegaan, wat volgens die Konvent van Wezel in 1568, nie net van buite deur die kinders geken moet word nie, maar ook met hulle harte aanvaar moet word.

Op die voetspoor van Calvyn, was die sestiende- en sewentiende-eeuse Gereformeerdes in Nederland dus oortuig dat die toelating tot die nagmaal deur 'n openbare belydenis van geloof voorafgegaan moes word. Die opvatting is gehandhaaf dat jy gedoop kan word sonder om dit te verstaan, maar dat jy die nagmaal net reg kan gebruik indien $j y$ in staat is tot ' $n$ vooraf ondersoek en 'n beproewing van jouself. Jy moet dus die essensie waarom dit gaan, begryp (De Gier 1989:291-293).

DKO 1619 artikel 61 is ook deur ander gereformeerde kerke byna woordeliks, of ten minste saaklik, oorgeneem.

In die geskiedenis van die Nederlandse Gereformeerde Kerk wat mettertyd in talle kerke verdeel het, het die GKN later in sy Kerkorde (KO) 'n eietydse weergawe van DKO 1619 artikel 61 opgeneem (Jansen 1952:266). In die hersiene GKNKO 1959 is dieselfde sake uit DKO artikel 61 geneem en 'uitvoeriger geregeld'. Nauta oordeel in sy kommentaar op GKN-KO 1959 artikel 75 dat hierdie artikel dieselfde strekking en hoofsaak as DKO 1619 artikel 61 dra.

Vir Nauta (1971) is die normale pad vir toegang tot die nagmaalstafel in 'n gemeente die aflê van 'n openbare belydenis van geloof in die gemeente. Hierdie bepaling geld vir hulle wat in dieselfde gemeente of een van die gemeentes in dieselfde kerkverband gedoop is. Fisiese ongeskikheid vir die aflê van ' $n$ belydenis en vir die gebruik van die nagmaal word deur die kerkraad afsonderlik hanteer. Die feit dat iemand die kinder- of verbondsdoop ondergaan het, is nie rede genoeg om so 'n persoon tot die nagmaal toe te laat nie. Hierdie afwykende houding kom so wyd in moderne Gereformeerde en Lutherse kerke voor dat Nauta (1971:268) verplig voel om die saak uitdruklik af te wys.

Volgens Nauta (1971) hou die 'afleggen van de belijdenis geloofs' in dat ' $n$ persoonlike beslissing gemaak word - ' $n$ beslissing wat 'n voorwaarde vir die gebruik van nagmaal is. Die kerkraad moet tevrede wees dat 'n persoonlike beslissing aanwesig is. Die redes waarom persone hulle geloof in die openbaar wil bely, moet ondersoek word. Hoewel Nauta die klem op die persoonlike beslissing laat val, bepleit hy ook ' $n$ ondersoek na leer en lewe (kyk Jansen 1952:268). Vir Nauta staan die eie mededelings van 'n persoon wat tot die aflê van die belydenis van geloof toegelaat word, sentraal. Die wyse waarop hierdie ondersoek geloods word, word nie kerkordelik bepaal nie omdat so 'n ondersoek, volgens Nauta (1971), nie gereglementeer kan word nie. Die ondersoek moenie die letterlike uitvoering van 'n wetlike voorskrif behels nie, maar met pastorale bekwaamheid en insig hanteer word. ${ }^{5}$ Nauta (1971) oordeel dat die ondersoek

5.Die Kerkorde van die Nederduitse Gereformeerde Kerk (NGKO 2017.17) bepaal in artikel 60.3 dat amptelike sake van kerklike opsig en tug 'pastoraal-kerkregtelik van aard is'. Dit bring mee dat ' $n$ kerklike ondersoek wat tot ' $n$ uitspraak vir of teen die
aansoeker of ondersoekte kan lei, kerklik-pastoraal en regverdig moet verloop. tot 'n kommissie of afvaardiging van die kerkraad beperk moet word, omdat' $n$ kleiner groep nodig is vir die vertroulike atmosfeer wat so 'n ondersoek vra. Die ouderlinge - lerend en regerend - speel 'n belangrike rol in die ondersoek. Indien die ondersoek gunstig verloop, hoef die kerkraad nie geken te word nie. 'n Ongunstige gevolg moet egter met redes en besonderhede wat dit toelig aan die kerkraad gerapporteer word (Nauta 1971:269). Dit wil dus voorkom asof Nauta in die 1970's in waters vaar waarin voornemende nagmaalgebruikers versigtiger hanteer word as in DKO 1619. Daarom skep hy 'n bykans vertroulike, beperkte kommissie van ondersoek na hulle wat tot die nagmaal toegelaat wil word.

Uit gereformeerde oortuiging koppel Nauta die belydenis van die geloof nie aan 'n 'bijzondere geestelijke bevinding' nie (kyk hiervoor vir die Nadere Reformasie) (De Jong 1986:216, 236). So 'n ervaring of bevinding kan, volgens Nauta (1971), nie 'n voorwaarde vir toelating tot die nagmaal wees nie. Die persoonlike beslissing lê daarin om die beloftes van die doop ter harte te neem en persoonlik te 'beaamd en ... [te] aanvaard'. Die verbondsdoop wat sonder die toedoen van die verbondskind toegedien is, moet, wanneer hierdie kind gereed is, deur hom of haar beaam en aanvaar word (vgl. Kock 1975:41), ${ }^{6}$ anders kan die tweede sakrament of die belofte van inblywing nie op die belofte van inlywing volg nie (vgl. Van der Linde 1983:203). In die hersiene GKN-KO van 1959 word 'n formulier van die kerkverband vir belydenisaflegging voorgeskryf. Persone uit ander GKNgemeentes of Gereformeerde kerke (ook in die buiteland) kan by die voorlegging van 'n attestaat toegang tot die nagmaal verkry, terwyl iemand uit 'n nie-Gereformeerde kerk na 'n ondersoek van die kerkraad dieselfde pad kan volg. Indien lede van ander gemeentes of kerke die kerkraad nie tevrede stel nie, kan die kerkraad sy vereistes vir toelating aan so 'n persoon voorlê (vgl. Jansen 1952:269-270; Nauta 1971:270-271).

GKN-KO artikel 75 sluit af met die bepaling dat toegang tot die nagmaal alleen verkry kan word indien die name van hulle wat dit verlang aan die gemeente vir goedkeuring voorgelê word (Nauta 1971:267). Met hierdie bepaling plaas GKN-KO kerklike bevoegdheid of gesag egter weer in die hande van 'n gewaande 'demokratiese' gemeente waarin lidmate, soos by die vrye toegang tot die nagmaal, die eintlike besluite neem.

\section{Gereformeerde belydenis toelating tot nagmaal: Ander Gereformeerde kerke}

Ander Gereformeerde kerke volg ook DKO 1619 artikel 61.

Die Gereformeerde Kerke in Suid-Afrika (GKSA) gee 'n Afrikaanse vertaling van DKO artikel 61. Dit gaan in GKSA-KO artikel 61 om toelating tot die nagmaal op 6.P. de B. Kock (1975:41 praat van ' $n$ verbond van versoening of verlossing binne die genadeverbond. 
grond van ' $n$ belydenis van die 'gereformeerde godsdiens ${ }^{7}$ en 'n 'goeie getuienis' van 'n vroom wandel. Sonder so 'n getuienis kan diegene wat uit ander kerke kom, nie tot die nagmaal toegelaat word nie (Gereformeerde Kerke in Suid-Afrika 2015:31; Kruger et al. 1966:365; Van der Linde 1983:203). Die Sinode van 1964 wysig artikel 61 redaksioneel deur na die woorde uit ander kerke, die uitdrukking van dieselfde kerkverband tussen hakies in te voeg (Kruger et al. 1966:365). Hierdie invoeging word in 1997 egter geskrap (Gereformeerde Kerke in Suid-Afrika 2015:31; Visser 1999:237). GKSA-KO wil daarmee waarskynlik dit net so stel dat gereformeerdes in die breë ook kan aansit by die tafel.

Kruger et al. (1966:365) wys daarop dat die gereformeerde kerkbegrip - anders as die kollegiale kerkbegrip - geen 'oop' nagmaalsviering ken nie. Visser (1999:240) noem die nagmaal 'n heilige sakrament wat nie deur deelnemers met onjuiste motiewe ontheilig moet word nie en waaroor die ouderlinge streng toesig moet hou. Lidmaatskap van die betrokke gemeente wat op 'n openbare belydenis van geloof volg, beteken in die kollegiale kerkbegrip lidmaatskap van die kerkverband as ' $n$ vrywillige vereniging van gelowiges 'n vereniging van enersdenkendes of kollegas in die geloof. Dit is hierdie lidmaatskap wat die nagmaal, ten minste in die gemeentes van die verband, vir so 'n persoon oopmaak en wat aan die lidmaat die 'reg' gee om self gekeur aan te sit by die tafel - sonder die bemiddeling en toesig van die betrokke kerkraad. Daarteenoor gaan dit vir Kruger et al. (1966:366) om die bevoegdheid en toesig van die 'plaaslike kerk' anders dreig die nagmaal om 'n demonstrasie van ekumeniese eenheid vanuit die mens te word of 'n eenheid van hulle wat uit eie wil met hierdie nagmaalsgemeenskap assosieer. Vir Kruger et al. (1966:366) moet lidmate van ander kerke of gemeentes, as die eie gemeente, toelating tot die nagmaal by die betrokke kerkraad soek met die voorlê van 'n attestaat of 'n bewys van goeie gedrag. 'n Belydenis van die 'gereformeerde godsdiens' of die gemeenskaplike geloof van die nagmaalsgemeenskap in God-Drieënig en die kernwaarhede van hulle verhouding met God, spruit uit die geestelike of geloofseenheid 'van die eners-gelowende mense in Christus'. Hierdie geloofseenheid, bewerk deur die Woord en Gees van God, kenmerk die nagmaal as 'n eenheidsmaaltyd en 'n voorwaarde vir toelating tot die sakrament. Anders gestel: die 'tafelgemeenskap van die Nagmaal ...', druk 'die onderlinge eenheid in geloofsoortuiging ...' uit (Kruger et al. 1966:366).

Gelowiges wat belydenis van geloof aflê, word nie daarmee as 'lidmate' aangeneem of die eerste keer lidmate van die kerk op daardie stadium nie. Die ou tradisionele onderskeid in die Nederduitse Gereformeerde Kerk (NGK) tussen 'lidmate' na hulle belydenis van geloof en 'siele' wat nog nie in die openbaar hulle geloof bely het nie, trek ' $n$ streep

7 Visser (1999.238) wys daarop dat die belydenis van die gereformeerde godsdiens hier (19nvoudig n belydenis van die drie-enige God en alles wat in diensen hier eenvoudig 'n belydenis van die drie-enige God en alles wat in die Byb geopenbaar en in die gereformeerde belydeniskrife uitgedruk word, beteken. Hierdie belydenis kan alleen volg op "deeglike kategetiese onderrig en indringend ondersoek na leer en lewenswandel deur die kerkraad' - 'n ondersoek wat soek n geloofskennis sowel as geloofsvertroue; 'n ondersoek na 'n vroom lewenswandel. deur die effek van die doop wat die opname in die genadeverbond nou as 'n dooplidmaat van die kerk verseël (vgl. Van der Linde 1983:203; Visser 1999:239). Toelating tot die nagmaal na die aflegging van die belydenis in GodDrieënig en van die kernwaarhede van die geloof soos gesamentlik aanvaar in die betrokke kerk, open die deure tot die nagmaal en volle kerklike voorregte waaronder deelname aan die kerkregering. Die belydenis van GodDrieënig as God én die vrome lewenswandel wat daarmee gepaard gaan, is in konteks 'n positiewe antwoord op die beloftes en eise van die Here by die doop. Dit is die gevolg van 'n gewortelwees en groei by die gelowige in die genadeverbond van God - in Christus deur die Heilige Gees - 'n kwessie van groei van doop- tot belydende lidmaatwees (Kruger et al. 1966:367-368).

In die GKSA word lidmate uit nie-Gereformeerde kerke met dieselfde belydenis of uit kerke met 'n nie-Gereformeerde belydenis na 'n kerkraadsondersoek, en waar nodig, aanvullende onderrig ten opsigte van hulle geloofsbelydenis of persoonlike beslissing vir God-Drieënig sowel as hulle geloofsinsig, ondersoek. Hierdie ondersoek evalueer ook hulle lewenswandel. Indien die uitslag positief is, word hulle tot die nagmaal toegelaat (Kruger et al. 1966:373-375; Visser 1999:239-242).

Die Christian Reformed Church in North America (CRCN) volg, ten opsigte van geloof as 'n voorwaarde vir toelating tot die nagmaal, ook die Dordts-Gereformeerde lyn. CRCN artikel 59 bepaal sonder meer dat dooplidmate tot die nagmaal toegelaat word na 'n openbare belydenis van hulle geloof in Christus - aan die hand van die voorgeskrewe vorm. CRCN-KO gee geen ouderdomsperk hiervoor nie. Voor die openbare belydenis van geloof in die gemeente, vergewis die kerkraad hulle van die motiewe, geloof en lewe van die kandidate soos getoets in 'n paslike proses. Die openbare belydenis van geloof maak van hulle belydende lidmate van die gemeente. Die name van hulle wat op hierdie wyse tot die nagmaal toegelaat word, word 'n week voor die belydenisaflegging aan die gemeente bekend gemaak. Belydende lidmate van 18 jaar of ouer wat daarby 'a commitment' tot die belydenisse van die CRCN en 'adult membership' in die CRCN maak, ontvang volle lidmaatsregte. Belydende lidmate met stawende kerklike bewyse ten opsigte van geloof en lewe uit ander CRCN-gemeentes, ontvang dieselfde voorregte. Belydende lidmate uit kerke wat met die CRCN in korrespondensie is as die mees intieme ekumeniese verhouding, verkry dieselfde voorregte nadat die kerkraad hulle van die inhoud en korrektheid van die ondersteunende dokumente vergewis het (Engelhard \& Hofman 2001:325). Hoewel die detail van ander kerke of kerkverbande verskil, handhaaf die CRCN dus die Christelike geloof en 'n vroom lewe (soos deur die Bybel bepaal) as voorwaardes vir almal - ook vir dooplidmate om tot die nagmaal toegelaat te word. Soos ander kerke in die Dordts-Gereformeerde tradisie is die CRCN nie ten gunste van 'n oop nagmaal nie. 


\section{Gereformeerde belydenis toelating tot nagmaal: Nederduitse Gereformeerde Kerk afwyking}

Teenoor hierdie kerke handhaaf die NGK 'n gemengde of nie-uniforme praktyk. Dit is 'n praktyk wat dieselfde pad loop as sy Dordtse eweknieë ten opsigte van die toelating van gedoopte gelowiges in die eie gemeente met ' $n$ geslote kommunie, maar ten opsigte van belangstellendes uit ander Nederduitse Gereformeerde gemeentes en ander kerkverbande, 'n oop nagmaal handhaaf. Dit is 'n gemengde praktyk wat die geloof as 'n vereiste vir toelating tot die nagmaal ten opsigte van dooplidmate in sy eie gemeentes respekteer, maar ten opsigte van die res dit aan die besluit van die betrokke indiwidu oorlaat. Hierdie praktyk getuig van 'n kerklike argeloosheid wat byna sorgeloos omgaan met die vier aspekte of konstantes wat van die nagmaal 'n sakrament maak.

Die nie-uniforme neiging ten opsigte van sakramente blyk reeds uit Nederduitse Gereformeerde Kerkorde (Nederduitse Gereformeerde Kerkorde [NGKO] 2017:14) se onderskeid in sy bepalings vir die sakramente van die doop en die nagmaal.

Vir die bediening van die doop, bepaal NGKO 2017 artikel 49.1 drie aanvaarde Dordts-Gereformeerde gebruike: die sakrament word deur' $n$ bedienaar van die Woord bedien (die Woord en formulier by die doop word deur ' $n$ kerklik-erkende of bekwame bedienaar van die Woord hanteer). Daarby geskied die doop met water en 'n, let wel, goedgekeurde liturgiese formulier (normaalweg deur die Algemene Sinode wat oor liturgiese beginsels en formuliere besluit); en dit vind in ' $n$ amptelike openbare samekoms van die gemeente of erediens waarin die Woord sentraal staan, plaas. Met laasgenoemde kan daar volgens NGKO 'hoë uitsonderings' gemaak word. Van die vereistes vir doopouers of wettige voogde uit die eie sowel as ander gemeentes of kerke - hulle wat die sakrament in die geloof moet gebruik of in geloof moet laat doop - word niks gerep nie. Ook nie watter persone in verskillende kategorieë van ouderdom en geestelike of geloofsontwikkeling gedoop word nie. Hierdie sake word elders gereël (Nederduitse Gereformeerde Kerk [NGK] 1986:507, 517; 2002:538). NGKO 2017 artikel 49.1 gee ook nie 'n kerkordelike voorskrif vir die gebruik in talle Nederduitse Gereformeerde gemeentes dat doopouers uit ander gemeentes of kerke dokumentêre bewys moet lewer dat hulle 'bekwaam' is om die vrae by die doop te beantwoord en in die posisie is om te beloof om hierdie kind 'van wie $\mathrm{u}$ die vader en moeder (of voog) is' in 'dié leer ... te onderrig en te laat onderrig' (Algemene Sinodale Kommissie 1988:61). Die geykte praktyk ten opsigte van die doop in Nederduitse Gereformeerde gemeentes is ' $n$ geslote sakrament waaroor die kerkraad van die gemeente waar die doop plaasvind, toesig hou. Daarby bly NGKO 2017 by 'n goedgekeurde formulier wat 'n produk van die kerkverband deur die Algemene Sinode is en daarom normaalweg beter verwoord en minder eensydig is as ' $n$ niegoedgekeurde (deur 'n meerdere kerkvergadering) produk uit die eie omgewing (NGKO 2017:14).
Oor die nagmaal bevat NGKO 2017 twee kort bepalings. Die eerste bepaal dat die nagmaal 'minstens' vier keer per jaar 'in elke gemeente gevier' word. Die tweede bepaal wie tot die nagmaal toegelaat word. Die woordjie bepaal skep die indruk dat die kerkraad - dit word nie woordeliks gestel nie - in die gemeente waar die nagmaal bedien word en die een wat normaalweg toesig hou, toelating tot die nagmaal beheer. Dit klink na 'n geslote kommunie waarin die kerkraad die toegang bepaal. Tog bepaal NGKO 2017 net dat sekere persone tot die nagmaal toegelaat word sonder om die wyse van toelating te bepaal of aan te dui wie hierdie toelating hanteer. Dit raak die toelating van belydende lidmate van die gemeente, dooplidmate wat reeds 'deur die kerkraad toegelaat is', besoekers uit andere Nederduitse Gereformeerde gemeentes en ander kerke. By die eerste twee groepe tree die kerkraad normaalweg toesighoudend op, maar by besoekers ontbreek die toesig. Sonder om met NGKO 1986 te bots (kyk NGKO 1986:13), besluit die Algemene Sinode van 1986 hieroor dat toelating tot die nagmaal geskied na aanmelding by die kerkraad of op 'n uitnodiging namens die kerkraad aan diegen wat, volgens eie oordeel, 'daartoe reg het' (NGK 1986:500, 628, 629). Die gesag van die toesighoudende kerkraad of ampsdraers gesamentlik word dus as ' $n$ 'reg' aan die individuele lidmaat oorgedra.

Uit die Dordts-Gereformeerde tradisie kan afgelei word dat daar niks nuuts onder die son is nie. Prediker 1:9 het weer waar geword. In die motivering vir hierdie oop nagmaal word aangevoer dat groot getalle besoekers wat by die kerkraad vir toelating tot die nagmaal aanmeld, die saak bottelnek en van laasgenoemde net 'n rubberstempel maak. Boonop kan die Algemene Sinode klaarblyklik aan geen ander manier dink om hierdie kwaad te besweer nie. In groot Nederduitse Gereformeerde gemeentes is gereformeerde beginsels skynbaar nie altyd prakties of werkbaar nie (NGK 1986:500).

Die NGKO 2017 laat dus ruimte vir 'n oop nagmaal. Die geloofstoets vir toelating tot die nagmaal word op die oog af gehandhaaf, maar 'n humanistiese individualisme wat kerkraadsgesag oplos in die vryheid en outonomie van sommige individuele gelowiges, voer hierdie toets uit. Die drie eie punte van NGKO artikel 49.1 oor die doop wat die Dordtse karakter daarvan weerspieël, ontbreek by NGKO artikel 49.2 oor die nagmaal. Dit sou wees dat die nagmaal as 'n Skrifgefundeerde en -verantwoorde maaltyd deur 'n erkende bedienaar van die Woord bedien word; dat die Woord hiervoor saamgetrek word in 'n goedgekeurde formulier, of ter wille van afwisseling, meer formuliere uit die kerkverband waarin daar dikwels meer perspektief, kennis en kerklike woordvaardigheid opgesluit lê (Strauss 2010:99); en dat die nagmaal in 'n erediens onder kerkraadstoesig as 'n geloofs- en eenheidsmaaltyd plaasvind.

Die NGKO is nie konsekwent in sy bepalings vir die sakramente nie. In sy besluit oor die toelating van gedoopte kinders van 16 jaar en ouer tot die nagmaal voor hulle belydenisaflegging, stuit die Algemene Sinode weer op 
geloof as voorwaarde. Die besluit van die Algemene Sinode van 1998 lui dat 'gedoopte kinders wat in Jesus Christus glo, aan die vereistes van 1 Korintiërs 11 voldoen en die begeerte het om nagmaal te gebruik tot die nagmaal toegelaat mag word'. Kerkrade moet hierdie besluit implementeer en sorg dat gemeentes begelei en in staat gestel word om dit uit te voer. Ouers speel in hierdie proses 'n deurslaggewende rol (NGK 1998:515). Op hierdie punt kies die Algemene Sinode dus vir 'n geslote kommunie waaroor die betrokke kerkraad toesig hou. Waar groot en moeilik beheerbare getalle vroeër moontlik 'n oop nagmaal vir besoekers gestimuleer het, verhoed die drukgang, veroorsaak deur die nuwe ongewone verskynsel van, soos dit populêr genoem is 'kinders by die nagmaal' of 'kinderkommunie', groter versigtigheid en 'n meer beginselgedrewe gereformeerde aanslag (NGK 1998:432). Ten opsigte van hierdie saak sal kerkrade dus hulle oog in die gereformeerde seil moet hou. In onseker en moeilike tye gryp gereformeerdes dikwels terug na die basiese waarhede.

\section{Kerkordelike stagnasie oor toelating tot nagmaal}

Uit die betoog tot dusver blyk dit dat gelowiges in die DordtsGereformeerde tradisie oor ' $n$ wye front saamstem dat die doop die inlywing van ' $\mathrm{n}$ mens as ' $\mathrm{n}$ dooplidmaat in die kerk sowel as die persoon se opname in die genadeverbond van die Here bevestig of verseël en dat die nagmaal sy of haar inblywing in die verbond en kerk versterk en verseël.

Hierdie insig lei tot die kerkordelike houding dat slegs gelowiges met vrug en sinvol - ten opsigte van die sakramentele werking daarvan - aansit by die nagmaalstafel. Normaalweg word hierdie gebruik in Gereformeerde kerke deur kerkrade eerbiedig en sover moontlik as deel van hulle toesigfunksie in die gemeente toegepas. Dit is dus 'n saak wat uit 'n kerkordelike hoek met ordemaatreëls gesteun kan word. 'n Gereformeerde kerkorde, normatief beskou, voorsien immers bepalings vir sleutelaspekte van die kerklike bediening, terwyl die Nederlandse Geloofsbelydenis artikel 29 as norma normata of norm, afgelei van die Woord, die regte of Woordsuiwere hantering van die Woord, die sakramente en tug in die kerk as die drie merktekens van die ware kerk uitlig (NG Kerk-Uitgewers 1982:29). Kortliks gestel: in die Dordts-Gereformeerde tradisie het ons by die sakramente met 'n sleutelaspek van die kerklike bediening te make.

In sy relevante koppeling van die nagmaal aan die kerklike tug, wys Du Plooy (1990) tereg daarop dat die wyse waarop die nagmaal in kerke funksioneer, 'min of meer as 'n barometer waarmee die geestelike klimaat ... in die kerklike lewe gemeet word', beskou kan word. Du Plooy (1990) bepleit toesig en tug by die tafel omdat die kerk hier met 'sy diepste kerkwees besig' is, sy 'uniekheid, heiligheid en afgesonderdheid'. In sy toelating tot en gebruik van die nagmaalstafel moet die kerk hiermee rekening hou. Die bybelse heiligheid en uniekheid van die nagmaal moet deur die uniekheid en heiligheid van die gemeente gekomplementeer en aangevul word. Albei hierdie eienskappe is die werk van God of vertoon sy stempel (Du Plooy 1990:145, 149). God se werk skakel die besluit van die individuele mens uit, naamlik om self te besluit of hy of sy deelneem aan die nagmaal.

Hierdie toedrag van sake maak dit nie vreemd dat Gereformeerde kerkordes bepalings oor toelating tot die nagmaal bevat nie. Dit gaan hier om kerkordelike bepalings wat in die Dordtse tradisie op 'n geslote nagmaal of toelating op grond van 'n belydenis van geloof en 'n vrome lewenswandel dui. Hierdie bepalings stuur die beoordeling van leer en lewe om sinvol by die nagmaal aan te sit. Soos in alle kerklike bedrywighede, word die hantering hiervan aan die oordeel en toesig van die plaaslike herders of die kerkraad oorgelaat. Dit gaan oor bepalings wat aandui dat hierdie Gereformeerde kerk anti-remonstrants en anti-kollegialisties is, en die toelating van iemand tot die nagmaalstafel nie aan hom- of haarself oorlaat nie. Hierdie bepalings dui verder aan dat die geestelike of geloofsgesag van kerk of gemeente nie in outonome individue setel nie, maar gesamentlik in Woordgebonde ampsdraers (Jonker 1965:11; Kleynhans 1985:138).

Die NGKO 2017 se hantering van die nagmaal is aangetoon.

Daar is gewys op die kontinuïteit van GKSA-KO artikel 61 met DKO 1619 artikel 61, die kontinue handhawing van 'n geslote nagmaal deur Dordtse Gereformeerdes. Daar is verder ook op die bybels-kerkordelike begronding daarvan gewys. NGKO artikel 49.2 se implisiete ruimte vir 'n oop kommunie vir besoekers vanweë kort, vae bepalings is ook aangetoon. Verder skyn daar van reformasie of verbetering in NGKO artikel 49.2 se kerkordelike hantering van nagmaal in die NGK geen sprake te wees nie. Hierdie moontlike gebrek blyk reeds duidelik uit NGKO se hantering van die nagmaal vanaf sy eerste uitgawe in 1964 tot nou. NGKO vertoon 'n geskiedenis van kort, vae bepalings en onduidelikhede wat geen orde in die verband van die NGK oor hierdie saak skep nie.

Die NGKO 1964 artikel 49(b) oor die nagmaal bepaal net dat die nagmaal minstens 4 keer per jaar in elke gemeente 'gevier' word. Die doop word ten minste verbind aan ' $\mathrm{n}$ bedienaar van die Woord en die erediens (NGKO 1964:10). Oor die toelating, wie waarmee by die tafel die leiding neem en wanneer dit gebeur, is daar geen woord nie. Die veronderstelling is skynbaar dat NGKO artikel 49(b) hieroor swyg omdat daar in die NGK konsensus oor die saak is. Immergroen vrae soos of iemand anders as die bedienaar van die Woord die nagmaal kan bedien, of dit buite ' $n$ amptelike erediens en los van die gemeente kan plaasvind en of 'n goedgekeurde formulier daarvoor nodig is, word nie hanteer nie. Van toelatingsvereistes of bewyse van 'n gereformeerde geloof en 'n vroom lewenswandel by moontlike gebruikers of besoekers, is daar nie sprake nie. Naas die frekwensie van nagmaalsvierings, swyg NGKO 1964 oor die nagmaal. 
Die NGKO 1964 artikel 49.2 bly onveranderd staan tot by NGKO 2002 artikel 49.2. In 40 jaar was daar geen aanvulling of verbetering nie!

Die rede(s) hiervoor is nie bekend nie. Die voor-diehandliggende rede is dat NGKO 1964 oor hierdie saak nie in die kerklike lewe gefunksioneer het nie. Gebreke rondom NGKO en die nagmaal is nie oopgevlek nie omdat NGKO ook nie hieroor geraadpleeg of dit bespreek het nie. Die geskiedenis van die Algemene Sinode sedert die eerste Sinode in 1962 getuig van 'n wisselende oop en geslote kommunie - 'n wisseling wat NGKO oor die nagmaal in sy eie kerkverband - indien hy sou kies - omstrede kon maak (NGK 1986:500). Dit gaan hier om 'n wisseling wat voor 1986 byna kenmerkend van die NGK was, maar wat daarna, met die besluit oor'n gemengde praktyk, voorlopig tot rus gekom het. Die huidige NGKO 2017 artikel 49.2 én hierdie praktyk, word sedert 2002 gehandhaaf. Byvoegings wat deur die Algemene Sinode van 2002 gemaak is en waarop gewys is, verbeter nie die saak nie. Hierdie mank NGKO artikel 49.2 staan tans dus ook, na byna twee dekades, onveranderd (NGKO 2002:20 artikel 49.2; 2004:21-22 artikel 49.2; 2007:22 artikel 49.2; 2017:14 artikel 49.2).

\section{Slot}

'n Behoorlike weeg van kerkordes in die DordtsGereformeerde tradisie dui daarop dat die sakrament van die nagmaal as ' $n$ geslote maaltyd onder talle gereformeerdes in hierdie kringe gehandhaaf word. Hierdie neiging bou via DKO 1619 artikel 61 op die eerste orde of kerklike handelinge in hierdie tradisie, naamlik dié van die Konvent van Wezel in 1568 (Pont 1981:76). 'n Geslote nagmaal in gemeentes is ekklesiologies-dogmaties verantwoord en met 'n ondersoek deur die kerkraad as die 'natuurlike' toets vir die gevraagde geloof en lewenswandel van voornemende gebruikers van die nagmaal, kerklik-histories beproef.

Met die uitsondering van sommige in Dordts-Gereformeerde kringe kon hierdie kerke hulle nooit met die kollegialisme of verenigingsreg oor toelating tot die nagmaal as ' $n$ vrye besluit van die individuele gebruiker versoen nie. Kerklik en dogmaties gaan die doop oor 'n verseëling van die inlywing van dopeling in die genadeverbond en die kerk van die Here, terwyl die nagmaal oor die inblywing van die gelowige in die genadeverbond en kerk van die Here gaan. Hierdie inblywing loop hand aan hand met 'n volharding in die Christelike geloof - 'n geloof waarna konsekwente Gereformeerde kerke by toelating tot die nagmaal vra, na lewensvoorbeelde soek en waarvoor verantwoorde gereformeerdes ten opsigte van die kudde van die Here verantwoording doen.

Die aanwesige geloof in Christus by die gebruiker is een van vier aspekte waardeur die nagmaal sy doel as 'n sakrament bereik. Dit is die doel van die nagmaal om hierdie geloof te verseël en te versterk, en daardeur 'n vroom lewenswandel te stimuleer. Die nagmaal is dus 'n geslote kommunie waarin geloof die enigste middel is waardeur die verseëlde boodskap ontvang kan word

\section{Erkennings Kompeterende belange}

Die outeur verklaar dat hy geen finansiële of persoonlike verbintenis het met enige party wat hom nadelig kon beïnvloed in die skryf van hierdie artikel nie.

\section{Skrywerbydraes}

Die outeur was die enigste outeur betrokke by die skryf van die artikel.

\section{Etiese oorweging}

Hierdie artikel volg alle etiese standaarde vir navorsing sonder direkte kontak met mens of dier.

\section{Befondsingsinligting}

Hierdie navorsing het geen spesifieke toekenning ontvang van enige befondsingsagentskap in die openbare, kommersiële of nie-winsgewende sektore.

\section{Verklaring van beskikbaarheid van data}

Data-deling is nie van toepassing op hierdie artikel nie, aangesien geen nuwe data in hierdie studie geskep of ontleed is nie.

\section{Vrywaring}

Die sienings en menings wat in hierdie artikel uitgedruk word, is dié van die outeur en weerspieël nie noodwendig die amptelike beleid of posisie van enige geaffilieerde.

\section{Literatuurverwysings}

Algemene Sinodale Kommissie, 1988, Handboek vir die erediens, NG Kerk-Uitgewers, Kaapstad.

Calvyn, J., s.a., Institutie, vert. A Sizoo, Meinema, Delft.

De Gier, K., 1989, De Dordtse Kerkorde - een praktische verklaring, Den Hertog, Bouten.

De Jong, O.J., 1986, Nederlandse kerkgeskiedenis, Callenbach, Nijkerk.

De Jong, O.J., 1987, Geschiedenis der kerk, 11e druk, Callenbach, Nijkerk.

Du Plooy, A. le R., 1990, 'Die heilige nagmaal en kerklike tug', Koers 55, 143-161. https://doi.org/10.4102/koers.v55i1-4.963

Engelhard, D.H. \& Hofman, L.J., 2001, Manual of Christian Reformed Church Government, CRC Publications, Grand Rapids, MI.

Gereformeerde Kerke in Suid-Afrika, 2015, Kerkordeboekie van die Gereformeerde Kerke in Suid-Afrika, Calvyn Jubileum Boeke Fonds (CJBF), Potchefstroom.

Heyns, J.A., 1973, Die Brug tussen God en mens, NG Kerk-Uitgewers, Kaapstad.

Heyns, J.A., 1992, Inleiding tot die dogmatiek, NG Kerkboekhandel, Pretoria.

Jansen, J., 1952, Korte verklaring van de Kerkorde der Gereformeerde Kerken, 3e druk, Kok, Kampen.

Jonker, W.D., 1960, 'Die bevoegdheid van die streeksinodes in die nuwe konsepkerkorde', Nederduitse Gereformeerde Teologiese Tydskrif 1(2), 33-37.

Jonker, W.D., 1965, Om die regering van Christus in sy kerk, Unisa, Pretoria.

Kleynhans, E.P.J., 1985, Gereformeerde Kerkreg III, NG Kerkboekhandel Transvaal, Pretoria.

Kock, P. de B., 1975, Christelike Wysbegeerte - Inleiding, Sacum, Bloemfontein.

Kruger, L.S., Du Plessis, H.L.M., Spoelstra, B. \& Spoelstra, T.T., 1966, Handleiding by die Kerkorde van die Gereformeerde Kerk in Suid-Afrika, Pro Rege, Potchefstroom.

Nauta, D., 1971, Verklaring van de Kerkorde van die Gereformeerde Kerken in Nederland, Kok, Kampen.

NG Kerk-Uitgewers, 1982, Ons glo ... Die Drie Formuliere van Eenheid en ekumeniese belydenisse, NG Kerk-Uitgewers, Kaapstad. 
Nederduitse Gereformeerde Kerk (NGK), 1986, Handelinge van die Algemene Sinode, sn, sl.

Nederduitse Gereformeerde Kerk (NGK), 1998, Handelinge van die Algemene Sinode, sn, sl.

Nederduitse Gereformeerde Kerk (NGK), 2002, Handelinge van die Algemene Sinode, sn, sl.

Nederduitse Gereformeerde Kerkorde (NGKO), 1964, Kerkorde van die Nederduitse Gereformeerde Kerk, NG Kerk-Uitgewers, Kaapstad.

Nederduitse Gereformeerde Kerkorde (NGKO), 1986, Die Kerkorde van die Nederduitse Gereformeerde Kerk, NG Kerkboekhandel Transvaal, Pretoria.

Nederduitse Gereformeerde Kerkorde (NGKO), 2002, Die Kerkorde van die Nederduitse Gereformeerde Kerk, Lux Verbi, BM, Wellington.

Nederduitse Gereformeerde Kerkorde (NGKO), 2004, Die Kerkorde van die Nederduitse Gereformeerde Kerk, Lux Verbi BM, Wellington.

Nederduitse Gereformeerde Kerkorde (NGKO), 2007, Die Kerkorde van die Nederduitse Gereformeerde Kerk, Bybel-Media, Wellington.
Nederduitse Gereformeerde Kerkorde (NGKO), 2017, Die Kerkorde van die Nederduitse Gereformeerde Kerk, sn, sl.

Pont, A.D., 1981, Die historiese agtergronde van ons Kerklike Reg I, HAUM, Pretoria.

Smit, C.J. \& Van der Walt, J.J., 1989, 'Die doop in die Gereformeerde Kerkorde', In die Skriflig 23(2), 59-73. https://doi.org/10.4102/ids.v23i90.827

Strauss, P.J., 2006, 'Die Dordtse tradisie en binding aan die belydenis', In die Skriflig 40(4), 649-666. https://doi.org/10.4102/ids.v40i4.363

Strauss, P.J., 2010, Kerk en orde vandag, SunMedia, Bloemfontein.

Strauss, P.J., 2012, 'Hoe geslaag is die kernwaarhede', in P. Theron (red.), Belhar geweeg, pp. 73-80, Kraal Uitgewers, Pretoria.

Van der Linde, G.P.L., 1983, Die Kerkorde, T.G. van Wyk Drukkers, Pretoria.

Van Wyk, J.H., 1991, 'Besinning oor die viering van die heilige nagmaal', In die Skriflig 25(2), 145-364. https://doi.org/10.4102/ids.v25i2.1375

Visser, J., 1999, Die Kerkorde in praktyk, EFJS Drukkers, Orkney. 